\title{
Infeksjon og prematur fødsel
}

\author{
Knut Jørgen Arntzen ${ }^{1,4}$, Anne Molne Kjøllesdal ${ }^{2}$, Lars Vatten ${ }^{3}$ og Rigmor Austgulen ${ }^{1}$ \\ 1. Institutt for kreftforskning og molekylarbiologi, Det medisinske fakultet, Norges teknisk-naturvitenskapelige \\ universitet (NTNU) \\ 2. Kvinneklinikken, Regionsykehuset i Trondheim \\ 3. Institutt for samfunnsmedisinske fag, Det medisinske fakultet, NTNU
}

4. Korrespondanse til: Knut Jørgen Arntzen, Institutt for kreftforskning og molekylærbiologi, Medisinsk Teknisk Senter, 7005 Trondheim Telefon 73598670 E-post Knut.J.Arntzen@medisin.ntnu.no

\begin{abstract}
SAMMENDRAG
Infeksjon i det intrauterine miljø kan være en viktig årsak til premature rier. Intrauterine infeksjoner underdiagnostiseres med dagens metoder. Ny kunnskap om molekylære mekanismer gir nye diagnostiske muligheter og kan åpne for alternative behandlingsformer.
\end{abstract}

Arntzen KJ, Kjøllesdal AM, Vatten L, Austgulen R. Infection and premature birth. Nor J Epidemiol 1997; 7 (1): 79-84.

\section{ENGLISH SUMMARY}

Prematurity is the cause of a substantial proportion of perinatal morbidity and mortality. It has become clear that intrauterine infection is an important underlying cause of premature labour. Unfortunately, our ability to diagnose these infections at an early stage is not well developed, and the effectiveness of available therapeutic agents is low. Premature labour caused by infection involves the activation of a network of inflammatory cytokines and the production of intrauterine prostaglandins. In this paper, we have attempted to describe recent developments in this area that are relevant to prematurity, and we also discuss whether this knowledge may provide possibilities for therapeutic intervention.

\section{BAKGRUNN}

I følge Medisinsk Fødselsregister ble det i 1994 født nesten 4000 barn før 37. fullgåtte svangerskapsuke. Dette utgjør ca. $7 \%$ av det totale fødselstall. I denne gruppen premature finner vi ca. $70 \%$ av den totale perinatale mortalitet. De siste 15 år har den perinatale mortalitet blitt betydelig redusert, sannsynligvis på grunn av satsing og kvalitetsheving innen neonatalomsorgen. Neonatalmedisin drives i dag så avansert at økt intensivering kan føre til at man beveger seg inn i et biologisk og etisk grenseland. Derfor er det kanskje mer hensiktsmessig å fokusere på årsak til prematuritet for å redusere den perinatale morbiditet/mortalitet ytterligere.

Omtrent halvparten av de premature blir født av gravide med spontane premature rier (1). Intrauterin bakteriell infeksjon som årsak til premature rier er ikke et nytt tema, men problemets kvantitative betydning oppfattes nå som større enn tidligere $(2,3)$. Det er vesentlig to grunner til infeksjoners uklare rolle ved prematuritet:

1. Det finnes ingen gode kliniske metoder for å påvise infeksjon i intrauterint vev.

2. Den patofysiologiske mekanismen ved en infeksjonsutløst prematur fødsel er bare delvis kjent.

I denne artikkelen vil vi prøve å belyse disse to problemstillingene og diskutere eventuelle terapeutiske muligheter.

\section{DET DIAGNOSTISKE PROBLEM VED INTRA- UTERINE INFEKSJONER}

Kliniske symptomer, funn av bakteriologisk agens i fostervann og histologisk undersøkelse av placenta kan gi holdepunkter for infeksjon i intrauterint vev. 


\section{Klinisk chorioamnionitt}

Denne tilstanden kjennetegnes ved feber hos mor, palpasjonsøm uterus og eventuelt illeluktende fostervann. Mye tyder på at de fleste intrauterine infeksjoner hos mor er subkliniske (4), og dersom infeksjonen er lokal, vil man ikke forvente å finne CRP stigning (5).

\section{Undersokelser i fostervann}

Fostervann kan samles ved amniocentese eller transvaginalt. Kontaminasjonsfaren ved transvaginal innsamling gjør at de fleste internasjonale studier benytter amniocentese. En rekke studier har påvist en statistisk sammenheng mellom premature rier og bakterier i fostervann $(2,6)$. Forekomsten av positiv bakteriologi ved premature rier varierer imidlertid fra $0-40 \%(2,7)$. Variasjonen kan skyldes ulik sensitivitet i dyrkningsteknikkene og ulike inklusjonskriterier i forhold til for eksempel vannavgang og tidsintervall mellom amniocentese og fødsel. I en studie ble det funnet bakterier i 35 av 92 undersøkte fostervann tatt ved amniocentese (7). De fødende hadde premature rier med intakte membraner, og fødslene skjedde innen 48 timer etter amniocentese. Like fullt har denne metoden tre kritiske momenter som reduserer sensitiviteten:

1. Infeksjoner i amnionhulen er forårsaket av ulike mikrober $(2,8)$, og arter av slekten mykoplasma ser ut til å forekomme hyppigst (9). Disse bakteriene vil ikke påvises ved de standardmetoder som brukes i Norge i dag.

2. Fostervann inneholder biologiske komponenter som hemmer bakterievekst. Lave bakteriekonsentrasjoner reduserer sensitiviteten ved mikrobiologiske dyrkningsteknikker.

3. Det er rapportert en økt risiko for prematur fødsel dersom det foreligger bakteriell vaginose eller andre infeksjoner i nedre genitaltraktus (10). Ved disse svangerskapene er risikoen for prematuritet øt også i de svangerskap der det ikke påvises bakterier i fostervann (10).

Enkelte virale infeksjoner kan være assosiert med prematur fødsel; det gjelder for eksempel infeksjoner med meslingvirus (11) og genital infeksjon med herpes (12). Det er uavklart om parasittære infeksjoner kan bidra til å sette igang fødselen, mens infeksjon med Candida Albicans ikke ser ut til å korte ned svangerskapslengden (13). Det er nærliggende å anta at forekomsten av reelle infeksjoner er høyere enn det estimat bakteriell oppvekst vil kunne gi, men den diagnostiske sensitivitet økes ikke ved å inkludere direkte gramfarging eller telling av leukocytter i fostervann i utredningen (14).

\section{Histologisk undersokelse av placenta med hinner}

I flere publikasjoner har leukocytt-infiltrasjon i placenta og hinner vært brukt som et indirekte tegn på infeksjon i intrauterint vev. Histologisk undersøkelse av placenta foretas ikke rutinemessig i Norge, men når det skjer, er det oftest etter klinisk mistanke om infeksjon. I internasjonale studier påvises histologisk chorioamnionitt ved premature fødsler hyppigere enn det påvises bakterier i fostervann $(15,16)$. Dette kan bety at histologisk undersøkelse har en høyere sensitivitet for deteksjon av bakteriell infeksjon, men leukocytt-infiltrasjon kan også være forårsaket av andre mekanismer (for eksempel mekanisk irritasjon under fødsel). Ved gjennomgang av 65 premature fødsler fant vi leukocytt-infiltrasjon i placenta hos 16 av 34 med premature rier. Til sammenligning hadde bare 1 av 31 med prematur forløsning uten riaktivitet $ø k t$ antall leukocytter (eget, upublisert materiale). Dersom leukocytt-infiltrasjonen er begrenset til membranene er sannsynligheten for positiv fostervannskultur lav (7). Når infiltrasjonen også påvises i placenta eller navlestreng finner man høy forekomst av positiv fostervannskultur (7). Disse observasjonene støtter hypotesen om at infeksjoner er oppadstigende fra det vaginale miljø, rammer først membraner og til slutt navlestreng og barn (Figur 1).

Både bakteriologisk undersøkelse av fostervann og histologisk undersøkelse av placenta har liten nytteverdi i den akutte kliniske situasjon fordi svar som regel foreligger for sent til å influere på behandlingsprosessen.

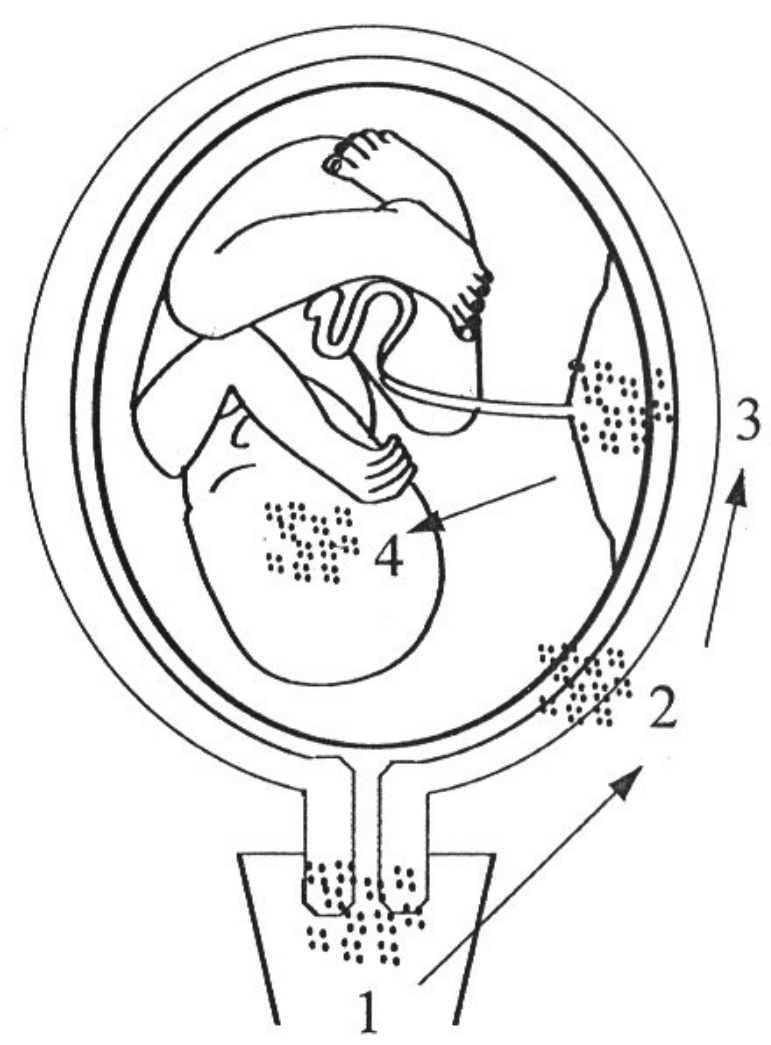

Figur 1. Stadier av oppadstigende infeksjoner fra genitaltraktus. Infeksjon i 1) cervix, 2) decidua, 3) placenta og 4) amnion eller foster. 


\section{INFEKSJON OG PREMATUR FØDSEL - MULI- GE PATOFYSIOLOGISKE MEKANISMER}

Statistisk er det vist at premature rier er assosiert både med forekomst av bakterier i fostervann og med leukocytt-infiltrasjon i placenta (8). Den kausale sammenhengen er imidlertid vanskelig å vise. Det faktum at man heller ikke vet hva som initierer normal fødsel til termin, viser hvor mangelfull vår biologiske forståelse er av disse fundamentale prosessene.

Forut for fødsel, enten denne skjer prematurt eller til termin, må uterus gå over fra en fase hvor den er relativt upåvirkelig av naturlig forekommende oxytocin, til en fase hvor oxytocin fører til kontraksjoner. Dels før, dels på grunn av, og dels parallelt med kontraksjonene, skjer en modning av cervix som gjør det mulig å tømme uterinhulen. Økt lokal prostaglandinproduksjon $\left(\mathrm{PGE}_{2}\right.$ og $\left.\mathrm{PGF}_{2 \alpha}\right)$ kan føre til uterine kontraksjoner og modning av cervix (17). Hva som initierer den økte produksjonen av prostaglandiner er imidlertid fortsatt uklart.

\section{Cytokiner som mediatorer ved infeksjoner}

Cytokiner er en samlebetegnelse på lavmolekylære proteiner som sender signaler mellom celler på en autokrin, parakrin eller endokrin måte. Noen av disse utgjør kroppens første respons ved kontakt med bakterier (toksiner). Tumor nekrose faktor (TNF), interleukin 1 (IL-1), interleukin 6 (IL-6) og interleukin 8 (IL-8) er eksempler på slike inflammatoriske cytokiner (18), og kan blant annet mediere septisk sjokk (TNF), feber (IL-1), akutt fase reaksjon (IL-6) og tiltrekning av leukocytter (IL-8) (18). I det intrauterine miljø kan disse cytokinene produseres av amnion, chorion og decidua ved stimuli fra toksiner (19), og man finner økte konsentrasjoner av disse cytokinene i fostervann ved premature fødsler der chorioamnionitt foreligger (20). Det er holdepunkter for at decidua først produserer TNF i forbindelse med en inflammatorisk aktivering. Deretter induseres produksjon av IL-1 og IL-6 (upubliserte data). Høye konsentrasjoner IL-6 i fostervann ser ut til å være den beste indikatoren på chorioamnionitt (21), og det finnes enkle teknikker (ELISA) som kan påvise IL-6 konsentrasjon i fostervann innen en time etter at prøven er tatt.

\section{Fra cytokiner til kontraksjoner}

Cytokiner har i seg selv ingen kontraherende effekt på uterus (22), men både TNF, IL-1 og IL-6 stimulerer amnion, chorion og decidua til økt prostaglandinproduksjon (23). Prostaglandin produseres ved aktiveringen av enzymet fosfolipase A2 (PLA2) og cyklooksygenase (COX) (17). Enzymaktiveringen bidrar til at arakidonsyre frigis fra cellemembranene og omdannes til prostaglandiner (17) (Figur 2). Chorion har stor evne til å inaktivere prostaglandiner, og det er derfor reist tvil om lokalt produsert prostaglandin når fram til muskulaturen i uterus (24). En ny rapport har imidlertid vist at den enzymatiske degraderingen av prostaglandiner blir hemmet ved infeksjoner (25). Dermed bidrar cytokiner både til økt produksjon og redusert degradering av prostaglandiner.

\section{Cytokiner og modning av cervix}

Aktivering av IL-1 ved infeksjon induserer IL-8 produksjon i cervix, som igjen fører til en rekruttering av nøytrofile granulocytter (26). Granulocyttene frigir kollagenase og elastase som gir degradering av kollagen i cervix (26). I tillegg stimulerer en rekke cytokiner cervix til prostaglandin-produksjon (27).

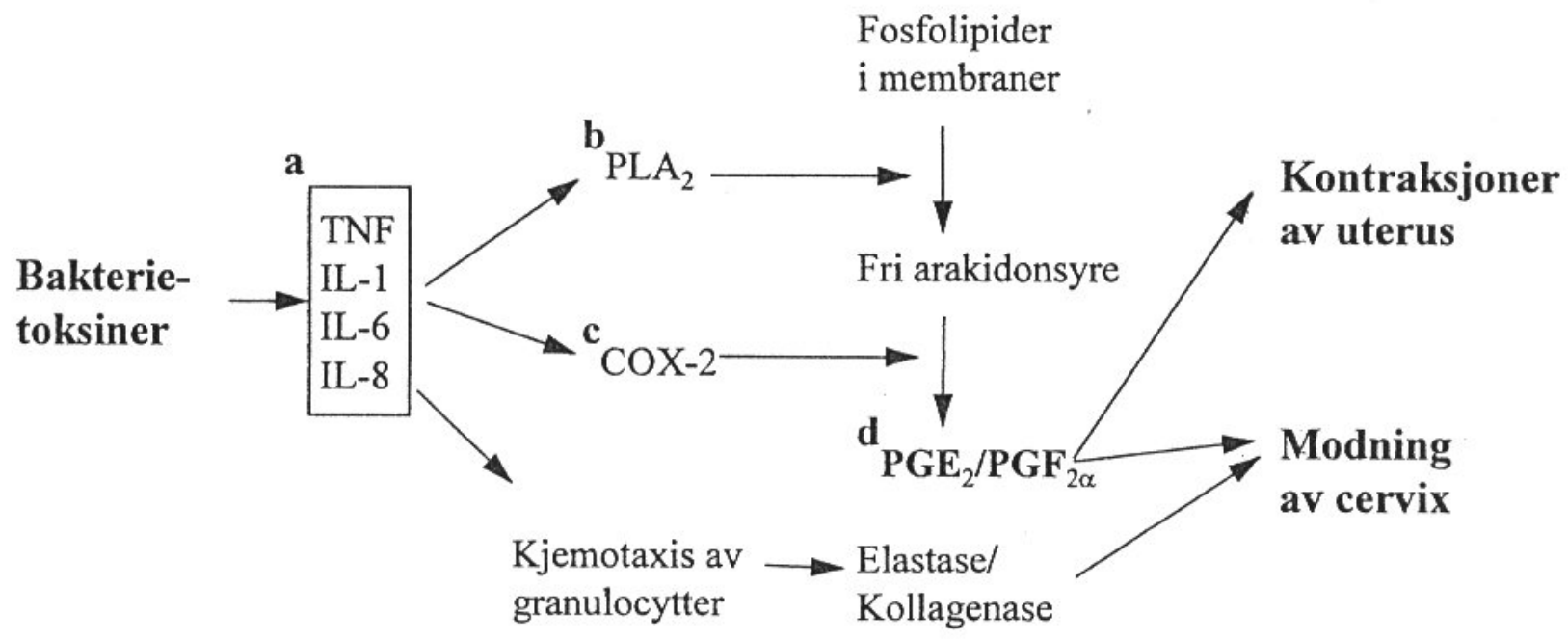

Figur 2. Infeksjon som årsak til prematur fødsel - tenkt mekanisme. a) Inflammatoriske cytokiner, b) Fosfolipase A2, c) Cyclooksygenase-2, d) Prostaglandin $E_{2}$ og $F_{2 \alpha}$. 


\section{Vannavgang og prematur fodsel}

Forut for premature fødsler finner det ofte sted subkliniske lekkasjer av fostervann, og slik lekkasje kan påvises ved å måle fibronectin i vaginalsekret opptil 4 uker før riene starter (5). Fibronectin finnes i den ekstracellulære matrix, og frigjøres ved skade/infeksjon av hinner (5). Nyere studier viser at høye nivåer av fibronectin i vaginalsekret i begynnelsen av 3. trimester kan predikere premature rier med en sensitivitet på $93 \%$ og en spesifisitet på 52-97\% $(28,29)$. Måling av fibronectin som screening kan tenkes brukt til å identifisere kvinner med høy risiko for å utvikle premature rier, og vil bli inkludert i svangerskapsomsorgen i USA (personlig meddelelse, D.I. Dudley, Universitet i Utah). Dersom det er riktig at opptil $40 \%$ av tilfellene med premature rier er forårsaket av infeksjon, kan måling av fibronectin være et nyttig hjelpemiddel til å identifisere en gruppe kvinner med høy forekomst av infeksjon i et tidlig stadium i prosessen.

\section{NY VITEN - NYE BEHANDLINGSALTERNATIVER VED PREMATURE RIER OG INFEKSJON?}

\section{Erfaringer med antibiotika}

Hypotesen om at infeksjon er en utløsende årsak til premature rier har vært grunnlag for randomiserte studier som har undersøkt om antibiotikabehandling kan forhindre for tidlig fødsel (2). Resultatene er ikke entydige i studier som har undersøkt om antibiotikabehandling kan forlenge svangerskapet der premature rier allerede er etablert (30). Derimot tyder en rekke nye rapporter på at behandling med metranidizol og erythromycin ved bakteriell vaginose tidlig i 2 . trimester, kan forebygge oppstart av premature rier og fødsler (31,32). Man diskuterer derfor om screeningundersøkelse for å avdekke bakteriell vaginose bør inngå i den generelle svangerskapsomsorgen siden behandling med antibiotika kan redusere forekomsten av for tidlig fødsel $(10,33)$.

\section{Cytokinmodulerende behandling ved premature rier}

Bruk av cytokinmodulerende behandling ved premature rier hos mennesker er ikke rapportert, men noen dyreforsøk og noen in vitro forsøk er gjort. Interleukin 1 reseptorantagonist (IL-1Ra) er en naturlig forekommende hemmer av IL-1 (34). Ved å gi IL-1Ra kan man forhindre IL-1 utløst prematur fødsel hos mus (35). IL10 er et cytokin med antiinflammatoriske egenskaper (36), og hemmer infeksjonsutløst prostaglandinproduksjon i decidua in vitro (37). Et generelt problem med cytokinmodulerende behandling er at den forutsetter en intervensjon før hele nettverket av cytokiner er mobilisert.

\section{Prostaglandinsyntesehemmere}

Enzymet cyclooksygenase (COX) omdanner arakidonsyre til prostaglandiner (se foran). COX finnes $\mathrm{i}$ to former, COX-1 og COX-2, hvor COX-1 normalt er uttrykt i de fleste celler og vev, mens COX-2 aktiveres av cytokiner ved infeksjon eller inflammasjon (38). Mens tradisjonelle ikke-steroide antiinflammatoriske medikamenter (NSAIDS) hemmer både COX-1 og COX-2, arbeides det nå med å utvikle spesifikke COX-2-hemmere da en forventer mindre bivirkninger ved selektive hemmere.

PLA2 frigjør arakidonsyre fra cellemembranen, og prostaglandin-produksjonen reguleres delvis via tilbudet på fri arakidonsyre. A framstille spesifikke PLA2-hemmere til terapeutiske formål kan derfor være aktuelt (39).

\section{SLUTTKOMMENTAR}

Mange studier har vist sammenheng mellom infeksjon og utvikling av premature rier. En sentral mekanisme er økt produksjon av cytokiner som fører til økt prostaglandin-produksjon. Prostaglandiner gir modning av cervix og kontraksjoner av uterus. Hvor ofte infeksjon er årsak til premature rier er usikkert, men tradisjonelle diagnostiske metoder vil gi et for lavt estimat. Måling av IL-6 i fostervann ser i dag ut til å være den mest lovende metoden både med hensyn til sensitivitet og analysetid.

Tokolytisk behandling har vist dårlig effekt på premature rier utløst av infeksjon, noe som kanskje skyldes at fødselsprosessen er kommet for langt når fødselen erkjennes klinisk. Måling av fibronectin i vaginalsekret kan bidra til å identifisere kvinner som bør utredes nærmere for mistanke om subklinisk infeksjon. Screening av gravide med hensyn til bakteriell vaginose bør kanskje inngå i svangerskapsomsorgen. Effekten av en eventuell tidlig intervensjon med antibiotika, antiinflammatoriske midler eller cytokinmodulerende behandling, gjenstår å se.

\section{REFERANSER}

1. Minkoff H. Prematurity: infection as an etiologic factor. Obstet Gynecol 1983; 62: 137-44.

2. Gibbs RS, Romero R, Hillier SL, Eschenbach DA, Sweet RL. A review of premature birth and subclinical infection. Am J Obstet Gynecol 1992; 166: 1515-28.

3. McGregor JA, French JI, Jones W, Milligan K, McKinney PJ, Patterson E, Parker R. Bacterial vaginosis is associated with prematurity and vaginal fluid mucinase and sialidase: results of a controlled trial of topical clindamycin cream. Am J Obstet Gynecol 1994; 170 (4): 1048-59. 
4. Lockwood CJ. Recent advances in elucidating the pathogenesis of preterm delivery, the detection of patients at risk, and preventative therapies. Curr Opin Obstet Gynecol 1994; 6: 7-18.

5. Dudenhausen JW, Korebrits C. [Critical evaluation of markers for premature labor. Vaginal $\mathrm{pH}$ value, vaginal bacteriology, fibronectin, C-reactive protein] Kritische Wertung der Fruhgeburtsmarker. Vaginaler pH-Wert, Vaginal-Bakteriologie, Fibronektin, CRP. Gynakologe 1995; 28 (3): 168-74.

6. Mitchell MD, Trautman MS, Dudley DJ. Immunoendocrinology of preterm labour and delivery. Baillieres Clin Obstet Gynaecol 1993; 7: 553-75.

7. Romero R, Salafia CM, Athanassiadis AP, Hanaoka S, Mazor M, Sepulveda W, Bracken MB. The relationship between acute inflammatory lesions of the preterm placenta and amniotic fluid microbiology. Am J Obstet Gynecol 1992; 166: 1382-8.

8. Romero R, Sirtori M, Oyarzun E, et al. Infection and labor. V. Prevalence, microbiology, and clinical significance of intraamniotic infection in women with preterm labor and intact membranes. Am J Obstet Gynecol 1989; 161: 817-24.

9. Romero R, Nores J, Mazor M, et al. Microbial invasion of the amniotic cavity during term labor. Prevalence and clinical significance. $J$ Reprod Med 1993; 38: 543-8.

10. Andrews WW, Goldenberg RL, Hauth JC. Preterm labor: emerging role of genital tract infections. Infect Agents Dis 1995; 4 (4): 196-211.

11. Atmar RL, Englund JA, Hammill H. Complications of measles during pregnancy [see comments]. Clin Infect Dis 1992; 14 (1): 217-26.

12. Brown ZA, Benedetti J, Selke S, Ashley R, Watts DH, Corey L. Asymptomatic maternal shedding of herpes simplex virus at the onset of labor: relationship to preterm labor. Obstet Gynecol 1996; 87 (4): 483-8.

13. Chaim W, Mazor M, Wiznitzer A. The prevalence and clinical significance of intraamniotic infection with Candida species in women with preterm labor. Arch Gynecol Obstet 1992; 251 (1): 9-15.

14. Romero R, Yoon BH, Mazor M, et al. The diagnostic and prognostic value of amniotic fluid white blood cell count, glucose, interleukin-6, and gram stain in patients with preterm labor and intact membranes. Am J Obstet Gynecol 1993; 169: 805-16.

15. Hillier SL, Witkin SS, Krohn MA, Watts DH, Kiviat NB, Eschenbach DA. The relationship of amniotic fluid cytokines and preterm delivery, amniotic fluid infection, histologic chorioamnionitis, and chorioamnion infection. Obstet Gynecol 1993; 81: 941-8.

16. Harger JH, Meyer MP, Amortegui A, Macpherson TA, Kaplan L, Mueller-Heubach E. Low incidence of positive amnionic fluid cultures in preterm labor at 27-32 weeks in the absence of clinical evidence of chorioamnionitis. Obstet Gynecol 1991; 77: 228-34.

17. Mitchell MD, Romero RJ, Edwin SS, Trautman MS. Prostaglandins and parturition. Reprod Fertil Dev 1995; 7: 623-32.

18. van Deuren M, Dofferhoff AS, van der Meer JW. Cytokines and the response to infection. J Pathol 1992; 168: $349-56$.

19. Menon R, Swan KF, Lyden TW, Rote NS, Fortunato SJ. Expression of inflammatory cytokines (interleukin-1 beta and interleukin-6) in amniochorionic membranes. Am J Obstet Gynecol 1995; 172: 493-500.

20. MacDonald PC, Koga S, Casey ML. Decidual activation in parturition: examination of amniotic fluid for mediators of the inflammatory response. Ann N Y Acad Sci 1991; 622: 315-30.

21. Gomez R, Romero R, Galasso M, Behnke E, Insunza A, Cotton DB. The value of amniotic fluid interleukin-6, white blood cell count, and gram stain in the diagnosis of microbial invasion of the amniotic cavity in patients at term. Am J Reprod Immunol 1994; 32: 200-10.

22. Oshiro BT, Monga M, Eriksen NL, Graham JM, Weisbrodt NW, Blanco JD. Endotoxin, interleukin-1 beta, interleukin-6, or tumor necrosis factor-alpha do not acutely stimulate isolated murine myometrial contractile activity. Am J Obstet Gynecol 1993; 169: 1424-7.

23. Mitchell MD, Trautman MS, Dudley DJ. Cytokine networking in the placenta. Placenta 1993; 14: 249-75.

24. McCoshen JA, Hoffman DR, Kredentser JV, Araneda C, Johnston JM. The role of fetal membranes in regulating production, transport, and metabolism of prostaglandin E2 during labor. Am J Obstet Gynecol 1990; 163: 1632-40.

25. Van Meir CA, Sangha RK, Walton JC, Matthews SG, Keirse MJNC, Challis JRG. Immunoreactive 15hydroxyprostaglandin dehydrogenase (PGDH) is reduced in fetal membranes from patients at preterm delivery in the presence of infection. Placenta 1996; 17: 291-7.

26. el Maradny E, Kanayama N, Halim A, Maehara K, Sumimoto K, Terao T. The effect of interleukin-1 in rabbit cervical ripening. Eur J Obstet Gynecol Reprod Biol 1995; 60: 75-80.

27. Calder AA. Prostaglandins and biological control of cervical function. Aust N Z J Obstet Gynaecol 1994; 34: $347-51$.

28. Nageotte MP, Casal D, Senyei AE. Fetal fibronectin in patients at increased risk for premature birth. Am $J$ Obstet Gynecol 1994; 170 (1 Pt 1): 20-5. 
29. Gaucherand P, Guibaud S, Awada A, Rudigoz RC. Comparative study of three amniotic fluid markers in premature rupture of membranes: fetal fibronectin, alpha-fetoprotein, diamino-oxydase. Acta Obstet Gynecol Scand 1995; 74 (2): 118-21.

30. Romero R, Sibai B, Caritis S, et al. Antibiotic treatment of preterm labor with intact membranes: a multicenter, randomized, double-blinded, placebo-controlled trial. Am J Obstet Gynecol 1993; 169: 764-74.

31. Hauth JC, Goldenberg RL, Andrews WW, DuBard MB, Copper RL. Reduced incidence of preterm delivery with metronidazole and erythromycin in women with bacterial vaginosis [see comments]. N Engl J Med 1995; 333 (26): 1732-6.

32. Morales WJ, Schorr S, Albritton J. Effect of metronidazole in patients with preterm birth in preceding pregnancy and bacterial vaginosis: a placebo-controlled, double-blind study. Am J Obstet Gynecol 1994; 171 (2): 345-7.

33. McGregor JA, French JI. Bacterial vaginosis and preterm birth [letter]. N Engl J Med 1996; 334 (20): $1337-8$.

34. Dinarello CA. Interleukin-1 and interleukin-1 antagonism. Blood 1991; 77: 1627-52.

35. Romero R, Tartakovsky B. The natural interleukin-1 receptor antagonist prevents interleukin-1-induced preterm delivery in mice. Am J Obstet Gynecol 1992; 167: 1041-5.

36. Danzer SG, Kirchner H, Rink L. Cytokine interactions in human mixed lymphocyte culture. Transplantation 1994; 57: 1638-42.

37. Dudley DJ, Edwin SS, Dangerfield A, et al. Effect of interleukin-10 (IL-10) on IL-6 and PGE2 production by murine decidual explants [Abstract]. Placenta 1996; 17: A.47

38. Arias Negrete S, Keller K, Chadee K. Proinflammatory cytokines regulate cyclooxygenase-2 mRNA expression in human macrophages. Biochem Biophys Res Commun 1995; 208: 582-9.

39. Glaser KB. Regulation of phospholipase A2 enzymes: selective inhibitors and their pharmacological potential. Adv Pharmacol 1995; 32: 31-66. 